\title{
Destroy the planet for the sake of the very rich? A plea for fair distribution as common sense
}

\author{
Elisabetta Grande ${ }^{1, *}$ \\ ${ }^{1}$ Università degli Studi del Piemonte Orientale - Amedeo Avogadro
}

\begin{abstract}
This paper will address from a peculiar point of view the key issue -raised today by Greta Thunberg and her peers- of the unlimited economic growth in a limited planet. It is its aim to point out how a relentless growth, while entailing dramatic ecological consequences in terms both of resources' consumption/destruction and of climate change, contrary to a common perception does not benefit everybody. In contrast, because of the unequal distribution of GDP and wealth that is largely driven by the legal systems such as politically shaped, it benefits only the very rich. This new understanding should finally lead the vast majority of us to stop asking for an unlimited growth and to join Greta Thunberg in her protest, calling for something different, namely a less unequal redistribution of what we have via different legal rules. Why in fact should we destroy the planet, such as we need it for our survival, just to make the very wealthy even more affluent?
\end{abstract}

\section{Introduction}

This paper addresses from a peculiar point of view the key issue - raised today by Greta Thunberg and her peers - of the unlimited economic growth in a limited planet.

As a lawyer, I would like to show how the unequal distribution of GDP and wealth, largely driven by the legal systems such as politically shaped, makes the assumption that a growing economy will benefit everybody illusory.

Conversely, the increase of GDP and wealth often brings about more poverty for the indigent and at best a great stagnation for the rest, except of course for the very rich.

Unveiling the imposture that lies under the misleading message in the very idea of a "good for all economic growth" could mean that people acquire a novel consciousness about the real consequences of producing, consuming and wasting more every day.

We all could abandon the wrong assumption that an estimated GDP increase will end up in an economic amelioration for all of us and that because of that growth the very poor will be less poor, the less indigent more prosperous and the very rich even richer. By discovering that the projections to benefit from the economic growth are erroneous for the vast majority of us, and that only the very rich can seriously expect to gain from it, we may finally stop asking for an unlimited growth that entails dramatic ecological consequences in terms both of resources' consumption/destruction and of climate change. In contrast, the great majority of us may finally join Greta Thunberg in her protest and ask for something different, namely a less unequal redistribution of what we have via different legal rules. Why in fact should we destroy our planet just to make the very wealthy even more affluent?

To prove my point I will first consider the United States' case, inasmuch the leading experience in Western tradition. I will then turn to the Italian case, in order to show how Italy (like most western countries) followed the United States' path. Finally, I will make the case that, contrary to a common rhetoric, high productivity and growth not even help poor people to live a better life in the global South.

\section{The case of the United States}

It is a fact that in recent decades, on varying dates depending on the country, the western world has experienced a substantial growth in GDP and wealth, at times entirely amazing, albeit accompanied by the squeezing of the middle class (even bottom 90\% [1]), and by an increase in extreme poverty. The rise of an unknown phenomenon like homelessness everywhere in the western world is the most obvious evidence of this growth.

Let me take the experience of the United States, which seems to be the leading model in the West. What we notice is that from the 1980s until now, while the wealth of the country practically tripled - from roughly 10 trillion in 1980 (29 trillion in today's prices) to 107 trillion in 2018 [2] -, extreme poverty almost doubled (it actually doubled from 1973 to 2014, according to the very conservative parameters of the Census Bureau [3]). In the same period, there was a great decline in the share

\footnotetext{
Corresponding author: elisabetta.grande@uniupo.it
} 
of the growing national income going to the bottom $90 \%$, while the top $1 \%$ saw an unbelievable rise, and an acceleration for the top $0.1 \%$ and $0.01 \%$ [4]. Wealth distribution over time became even more unequal: the share of wealth held by the top $1 \%$ rose from $25 / 30 \%$ in 1989 to $38.6 / 40 \%$ in 2016 [4, 5]. Three people today have more wealth than the bottom half of the population and the four hundred richest persons own as much wealth as two thirds of Americans [6]; the top 10\% of the wealthiest people, moreover, own $80 \%$ of the entire national wealth $[7,8]$. On the other side of the spectrum, the share held by the bottom $90 \%$ fell from $33.2 \%$ in 1989 to $22.8 \%$ in 2016 [7,8], with the bottom $60 \%$ having seen a decline from a $5.7 \%$ share in 1987 to a $2.1 \%$ share in 2014 [5].

According to many sources, the increased income and wealth of the wealthiest is accelerating at the expense of the bottom $90 \%$ of the American population $[4,9,10]$. If this grabbing of an ever-wider share of the American wealth and income by the very rich is going to continue, it will inevitably affect the wellbeing of an increasing part of the population. In sum, whatever has happened in recent decades to the poor, who did not become less indigent despite the amazing growth of the United States' GDP and wealth ${ }^{1}$, but became even poorer, ending up homeless in the worst cases $^{2}$, seems likely in the future to affect a larger share of the American population. The illusion of a "good for all economic growth", which makes everyone dream about becoming better off whenever the economy grows, will crumble more and more against the wall of growing inequality.

How did the wealthiest exploit the poorest in the United States?

In a large part, it has been the result of a legal system that is internationally and nationally organised to allow the richest to become richer at the expense of the most vulnerable. At the international level, a treaty like the GATT, which later merged into the WTO, has brought about some crucial consequences, which would not have occurred if the countries had ratified the Havana Charter instead. This provided indeed for the sanctioning of countries that did not respect the minimum standard of workers protection established by the ILO. On the contrary, the GATT, together with the later WTO, which took effect in 1948 and 1995 respectively, not only did not, and still do not, sanction such violations, they even sanction those countries that do not import from the ones that violate them! Over time the new international rules have resulted in strong competition among the poorest workers in the world, in the horrible exploitation of workers in the global south (which we cynically call

\footnotetext{
1 The percentage of American poor, even when very conservatively calculated - as is the case in official statistics has never been lower than in 1973 [11].

${ }^{2}$ Starting from the mid-1970s, as already mentioned, extreme poverty (that is people whose income is below one-half of the poverty threshold) grew enormously in the United States. Since the 1980s, moreover, a new social phenomenon of homelessness hit the United States, never disappearing [12].
}

"GDP growth") and of course in a substantial wage decline for the unskilled workers in the United States (and in the global north generally).

American workers did not even gain any protection from the national legal system when, due to the global race to the bottom, their working conditions began to worsen badly from the mid-1970s. Unlike in Roosevelt's days, when social legislation contrasted with the exploitation of workers that extensive economic freedom would have otherwise continued, the market completely prevailed over workers' legal safeguards from Reagan's. Abandoned by the law, many American workers started to work for very low salaries, especially in the third sector, since the intense factory relocation phenomenon, driven by the international legal order mentioned above, vastly reduced the first one. Their work became more and more insecure, not only because they could (and can) be easily fired, but especially because their working hours became extremely erratic, depending on the will and the interests of the employer, who got used to dumping the risks of their business on them. New forms of extremely precarious working agreements, such as the "on call shift", entered the working scenario with complete impunity, together with a compulsory conflict resolution mechanism, such as the mandatory arbitration, that effectively cancelled out any workers' rights.

The minimum wage, a safety net for the otherwise exploited worker, has never again reached the threshold that existed during Carter's presidency. At that time, the minimum wage was enough to allow one person to sustain themselves and two more people with their job. It decreased from Reagan's times to the point that it is today not even enough for a single worker to live a decent life.

A new kind of worker had arrived: the working poor. The law of the strongest, in sum, overcame the force of law.

It is therefore surely not a surprise to discover that from 1979 to 2011 the hourly wages of all workers up to the 70 percentile stagnated; or that in the same time-span the hourly wages of the poorest workers, corresponding to the 10th percentile, experienced a decline, while the hourly wages of the top silver (i.e. the top $0,1 \%$ ) workers grew by $278 \%$ [13]. The pay-cheques of CEOs, of course, have seen almost inconceivable growth: in 2007 a Wal-Mart CEO was earning in two weeks what a WallMart worker would have earned in their entire life if they had been able to retain a job there [14]. Today, according to a recent study commissioned by the Associated Press, workers would need to work 158 consecutive years to earn what their bosses make in one year [15]. Furthermore, a full-time Amazon worker would need to toil for 2.5 million years to generate as much money as Jeff Bezos has [6].

Nor is it a surprise that the median wage of a male worker is lower today than it was in $1973[11,16]$, albeit there being very low unemployment; or that in 2016 Oxfam announced that nearly half of the workforce had 
an hourly pay too low to thrive in $2015^{3}$. In that year in the United States, 41.7 million American workers were earning under $\$ 12$ an hour, according to Oxfam America, when the "poverty level wage" was $\$ 11.66$ (in 2015 dollars) [18].

Since 1973 , thanks to a dastardly legal system, "a stunning disconnection between the economy's potential for improved pay and the reality of stunted pay growth" (or even of a pay decrease at the lower levels), "one that was not present in prior decades" [13], started to characterise the labour market. Since then the great majority of workers have not profited from the growth of the economy, and many have ended up in poverty. In the meantime, another tsunami hit the new working (and not working) poor: the retreat of the welfare state that Franklyn Delano Roosevelt first, and Lyndon Johnson afterwards, effectively implemented.

It is obviously not the place to thoroughly discuss the remarkable decrease in the government's help for poor people that has taken effect in the United States since 1980, however, in order to understand how much the legal system can be held responsible for the production of poverty in the United States' growing economy, it is necessary to highlight the war, not on poverty, but rather on the poor themselves, which started with Ronald Reagan and continued afterwards. It hit especially hard under Bill Clinton and his Personal Responsibility and Work Opportunity Reconciliation Act of 1996 (PRWORA). After the passage of this law, the number of individuals receiving federal welfare declined dramatically, in particular mothers with small children. They totalled $14,200,000$ in 1994, but were 3,800,000 in 2014 [19]. Fifteen years after Clinton's Reform, scholars such as Edin and Shaefer, noted that the number of single mothers with children living on 2 dollars or less a day had doubled [19].

In a period of impressive increases in the price of housing, the government also dramatically reduced rental subsidies for the poor, substantially replacing pure public housing with public/private partnership solutions. This gave an advantage to private owners and companies over poor people. Today, only one out of four people who qualify to receive government housing assistance receive it, while, thanks to a legal system that protects the richer private owner over the poor tenant, evictions of poor tenants from private property have reached astonishing rates [20]. On the other side of the moon, that of the richest Americans, there has been significant government assistance to help them to live in their own homes, particularly luxurious homes. For instance, it has been calculated that in 2008 the tax deductions of homeowners - including interest on mortgage deductions, home equity loan interest deductions, property tax deductions, deductions in selling costs and

\footnotetext{
3 "The state of working America is hurting: 41.7 million workers earn under $\$ 12$ an hour and 58.3 million workers earn under $\$ 15$ an hour-wages that are too low for families to thrive. Nearly half of all private sector workers lack a single paid sick day." [17]
}

capital gains exclusions - amounted to $\$ 171$ billion. This was four times the amount that the government spent on poor tenants to help them keep their rental homes, which amounted to something like 40 billion. "Americans might have recast their idea of who got what for 'free' and from where", wrote a scholar addressing this very issue [21].

The current president is trying to reduce any social help to the poor even more, and with Donald Trump the war on the poor has actually intensified. He is attacking the supplemental nutrition assistance program (SNAP), formerly and commonly known as the Food Stamp Program, which provides assistance in purchasing food for low- and no-income people living in the United States. He is also trying to drastically reduce Medicaid, the healthcare program for poor people, together with the residual rental assistance program, by attempting to link them to working conditions that are difficult to meet.

Astonishing tax cuts for the richest over the last decades, although contributing to explain the increasingly unequal distribution of wealth and income after tax in the United States, also explain the reduction in social programs, which would otherwise have limited the problems faced by poor people. During Ronald Reagan's presidency the top marginal income tax rate decreased from $70 \%$ to $28 \%$, and although it increased afterwards, it fluctuated well below the previous threshold, never approaching the rate implemented during the Carter era or the $90 \%$ rate, effective in the days of a President Eisenhower, who was most certainly not a communist.

These are in a nutshell the changes that in a recent past took place in the United States legal domain such as politically shaped. The result has been that the most vulnerable could not benefit from the growing economy worsening in fact their economic conditions to the point that many people have become homeless.

The emergence of homeless people as a social phenomenon, and their growing number from the 1980s on (involving more than one in every 30 children in 2013 $[12,22])$ in times of amazing substantial growth in national wealth and income, is indeed counterintuitive $[23,24]$. Only the actual operation of a regressive politically shaped legal system can help explain it: a legal system that furthers an inverse redistribution of income and wealth, allowing the rich to exploit the poorest.

\section{The United States: A leading model for the Global North? The Italian case.}

Cesare Pavese, a great Italian writer, used to say that any tragedy that takes place on a large scale in the United States, would later affect Italy on a smaller scale. Judging from the growing number of poor and homeless people in times of (more or less) economic growth all over Europe, Pavese's prediction certainly seems to fit a large part of the global North.

If we focus on the Italian case, we can see how closely Italy has imitated the United States' regressive politically driven legal model since the 1990s, giving 
rise to an inverse redistribution of both wealth and income as well.

Examining some data will allow us to grasp the strong analogies between the American and Italian paths. As in the United States, also in Italy there has been a simultaneous growth of national wealth, accompanied by a contrasting growth in the national poverty rate, for the past few decades.

According to Bankitalia, Italian wealth doubled from 1995 to 2013 [25]. According to the Crédit Suisse Research Institute, it grew from 5 and half to 10 and half trillion dollars between 2000 and 2018 [26]. That is an increase in wealth per adult in current prices from 120,005 to 217,787 dollars [26].

Yet absolute poverty in Italy grew enormously from 2000 to 2017. When individuals are taken into consideration, it increased from an incidence of 5.1\% (corresponding to 2,937,000 people) to an incidence of $8.4 \%$, (corresponding to 5,058,000 people). When families are taken into consideration, absolute poverty in Italy basically doubled, increasing from an incidence of $4.3 \%$ (corresponding to 954,000 families) in 2000 to $6.9 \%$ (corresponding to $1,778,000$ families) in 2017 [27$30]$.

In recent years, Italy has experienced an acceleration of both extreme poverty and extreme affluence. Between 2015 and 2016 extreme poverty grew from $18.3 \%$ to $26.8 \%$ [31], and in the same year the number of Italian millionaires increased by 6000 more [32]. In 2017 when the rate of unemployment was decreasing for the fourth consecutive year [33] and the Italian GDP increased by $1.5 \%$ in a year [34] - absolute poverty increased to $8.4 \%$ (corresponding, as above, to 5,058,000 people) from $7.9 \%$ in the previous year $(4,742,000$ people). Wealth per adult in current prices, however, increased from 188,741 in 2016 to 206,929 euro in 2017 $[29,30]$, and the number of Italian millionaires increased in the same span of time by 138,000 [35].

Economic growth has therefore not involved everyone. On the contrary, as in the United States, economic growth has seen the poor become even poorer, while the wealthiest became even wealthier. In both countries, the distribution of income and wealth has been concentrated more and more at the top level, and for the very same reasons.

In the last 19 years, since the beginning of the new millennium to the first semester of 2018 , the share of national wealth held by the richest $10 \%$ of Italians on one side, and by the poorest half on the other side, has been diverging more and more. The former has increased since 2009 , reaching $56.13 \%$ in June 2018 (it was $50.57 \%$ in 2000); the latter gradually, yet constantly, fell from $13.1 \%$ to just $7.85 \%$ in the same period of time. At the end of first semester of 2018, Italian net wealth was 8,760 billion euro, up by 521 billion since the first semester of 2017, yet its distribution was such that the wealthiest $20 \%$ owned $72 \%$ of it (up from $66 \%$ in the previous year), the following $20 \%$ of the Italian population owned $15.6 \%$ of it, and the poorest $60 \%$ shared just $12.4 \%$ (down from $14.8 \%$ in the previous year) [36]. The number of millionaires in Italy from 2017 to 2018 grew, by the way, by 200.000 more [37]. It is certainly a less unequal distribution than in the United States, but the trend is obviously the same: an increasingly large part of the population, the poorest, is gradually but constantly less and less involved in the Italian economic growth - and the poorest among the poor are rapidly becoming even poorer.

Italy is walking the same legal path as the United States, albeit slightly Italy has been involved in the new international commercial order described above for a long time, but until the 1990s Italian labour law was able to protect Italian workers. The recent intense relocation of manufacturing industries, however, combined with a new labour law that allows for increasing work insecurity, has led to a great reduction in both real wages and hours for the most vulnerable workers.

The combination of the last economic crisis and an increase in factory relocation, from 2008 to 2014 has meant that the Italian manufacturing and building sectors together have lost more than 900,000 jobs. The service sector was able to regain something like 100,000 of the lost jobs by 2014, but by November 2017 the number of employed people caught up with the best pre-crisis moment, reaching 23,133,000 units, just a little less than the 23,171,000 employed in April 2008 (the largest in Italy since Istat, the Italian statistics institute, started to record employment numbers). As Leonello Tronti points out, however, "to recover the volume of hours effectively worked in 2008, it would take 1 million and 743,000 more employed people" [38]. Due to the increasingly precarious nature of their jobs, people are now working fewer hours than before [39]. They are also mostly working in the poorly paid third sector, which has partially replaced the first one in Italy too. Moreover, since the 1990s, when labour laws started to reduce workers protection, employees experienced a wage reduction that has deepened in recent years for the poorest and less skilled among them. "The latest annual Istat report says that, between 2007 and 2016, the already low real earnings of hotels and restaurants workers (25.046 euro before-tax) fell to 24,402: down by $2.6 \%$. Even greater drops have concerned the purchasing power of workers in the healthcare and care sectors (down by $8 \%$ ), in the education sector (down by $10.4 \%$ ), in the public sector (down by $7.9 \%$ ), in financial and insurance activities (down by 9.5\%), among porters, packers and delivery personnel (down by $4.5 \%$ ). It is this precisely the type of job that have seen an occupational rise. More jobs, yet poorly paid: this has been the tradeoff', writes a commentator [40].

The trend towards the impoverishment of the poorest of workers, increasingly involving the most poor even in times of economic growth, started in 1998. Until 1992, real earnings were growing for every worker, although not homogeneously. In 1998, however, a decline in workers earnings began. The plunge was particularly dramatic for the poorest 10 and 25 percentiles, who lost up to 35 and 20 percentage points respectively, compared with 1985; median percentiles earnings stagnated until 2010, when they too experienced a decline of $5 \%$ compared to 1985 earnings. Only the workers in the richest 75 th percentile and above maintained their living standard, and the Gini index 
increased, together with the percentage of the working poor on one side and that of the working rich on the other [39].

In both the United States and Italy, estate and income tax cuts greatly privileged the rich over time. In Italy since the 1990s moreover, the increase in indirect taxation, together with the privatisation of services, has led to higher prices for anyone for the profit of the few, generating, like in the United States, an inverse redistribution of income and wealth.

The once strong Italian welfare state is now in retreat. Social housing has declined enormously, to the point that only one out of three people who have the right to the subsidy actually receive it. Rent control is a distant memory and evictions are on the rise. The national health system is no longer covering the poor, as demonstrated by the $12,200,000$ Italians who gave up on treatments for economic reasons in 2016 [41] $]^{4}$.

The currently increasing number of homeless people, a phenomenon without precedent in Italy, is therefore no surprise. In the new political-legal order, Italian homeless in their unprecedented composition made of families and young and educated people, like the American homeless are doomed to persist and increase, any economic recovery notwithstanding.

\section{Is the global south performing any better?}

According to a common rhetoric, high productivity, with its implications for irreversible ecological disasters, is however helping poor people in the global south to live a better life. According to this rhetoric therefore, the present political-legal-economic order would benefit the global south and ultimately restore the consequences of colonial plunder. It would finally give it, in sum, what it has been deprived of for centuries, to the detriment for once of the (squeezing) middle class of the global north [43].

However only a careless look at the international data would lead to such a conclusion.

For example, the elephant curve, representing (according to the recent World Inequality Report) the total income growth by percentiles across all world regions from 1980 to 2016 [1, 43], does not tell us that the lowest percentiles of the global population living in the global south (the "emerging countries" in the report) are really better off. The sudden impression of a substantial growth enjoyed by the poorest people on earth (those representing the elephant's bottom) vanishes if one considers what such an income increase really means. It means a few dollars for each of the people in the bottom $50 \%$, who were rewarded with just $12 \%$ of the total increase. That is against the extraordinary growth of the top percentiles of the global population: the $1 \%$, and especially the 0.01 and $0.001 \%$, who

\footnotetext{
${ }^{4}$ In 2017 on the other hand Italians spent on private health the amazing figure of 39,7 billion euro [42].
}

received $27 \%$ of the growth, in addition to starting from a totally different, and very high, economic base.

The income growth of the poorest on earth is also what brought the World Bank to declare in 2018: "The world attained the first Millennium Development Goal target - to cut the 1990 poverty rate in half by 2015five years ahead of schedule, in 2010" [44]. In order to persuade the public that the present world economic growth is "good for all", the United Nations set a goal at the dawn of the new millennium, of eradicating poverty in the so called developing countries by 2030. To achieve what was an impossible goal to attain, they resorted to a few tricks, so that the fantasy looked real. Not only did they set an unreasonably low poverty threshold, one that changed the percentage of those living in poverty from $40 \%$, when calculated according to the official threshold employed in Sri Lanka, for instance, to just $4 \%$, but they also did not take into consideration the massive urbanisation that makes it extremely difficult to compare an exchange economy with a market one, no matter the criteria employed. People in a rural context may have no money, but they may live in a better economic situation than someone in a city who can spend 2 dollars a day.

The most impressive trick used to prove the impossible reduction of global poverty was the setting over time of a different and formally higher poverty threshold that in fact was always lower than before, since the new standard did not cover the real dollar depreciation. ${ }^{5}$

All these tricks notwithstanding, the World Bank has to admit today that poverty reduction is slowing and that: "The latest projections show that if we continue down a business-as-usual path, the world will not be able to eradicate extreme poverty by 2030 " [44].

According to the most careful scholars, global extreme poverty (except for China whose numbers seem to be overestimated anyway) didn't really experience a reduction. By fixing the threshold of poverty to the more reasonable standard of 5 dollars a day, extreme poverty is found to involve 4.3 billion people, almost $60 \%$ of the global population, and from 1990 to nowadays it has incurred a rise, not a fall [45].

The ninth edition of the Global Wealth Report published by the Crédit Suisse Research Institute reported: "During the twelve months to mid-2018, aggregate global wealth rose by $\$ 14.0$ trillion (4.6\%) to a combined total of $\$ 317$ trillion, outpacing population growth. Wealth per adult grew by $3.2 \%$, raising global mean wealth to a record high of $\$ 63,100$ per adult (...)

\footnotetext{
${ }^{5}$ In early 2000 , the poverty threshold was set at US\$1.02 U.S. a day in 1985 PPP. It was then adjusted upwards a number of times, purportedly to be in line with evolving living costs in the countries. In late 2000 it was adjusted to US\$1.08 a day in 1993 PPP; then in 2008, to US\$1.25 a day in 2005 PPP; and finally in 2015 , to US $\$ 1.90$ a day in 2011 PPP. For an account of how this ended up lowering instead of raising the threshold, therefore reducing poverty percentage only on paper, see Jason Hickel [45]
} 
This continues its unbroken run of growth in both total wealth and wealth per adult every year since 2008" [46].

Yet in 2019, Oxfam stated: "The world's 26 richest people now own the same wealth as the poorest half of humanity". The report found that billionaires around the world saw their combined fortunes growing by $\$ 2.5$ billion ( 2.2 billion euro) each day in 2018, an annual increase of 12 percent. "The 3.8 billion people at the bottom of the scale meanwhile saw their relative wealth decline by $\$ 500$ million each day, or 11 percent last year", Oxfam said however [36].

The World Inequality Report predictions do not give us any more hope either. "If we now look at the top of world wealth distribution - as measured by Forbes billionaire rankings- we found that the top wealth holders' share has increased a lot faster than average wealth holders: $5.3 \%$ since 1987 for the top $1 / 20$ million, and $6.4 \%$ for the top $1 / 100$ million. By definition, this is an evolution that cannot continue forever: if top wealth holders were to grow on a permanent basis at the speed that is three to four times faster than average wealth in the world, then billionaires would ultimately come to own $100 \%$ of the world wealth" [1].

\section{Conclusions}

In the end, economic growth seems to mean increasing wealth for very few among us, and a growing poverty for many more of us. It will also mean, as we all know, the destruction of our own species in a very near future. We should then seriously consider caring about a less unjust distribution of the enormous wealth we have produced, rather than producing more at the expense of our own survival. Why, indeed, shall we destroy our planet, such as we need it for our self-preservation, just to make the very wealthy even more affluent?

\section{References}

1. The World Inequality Lab, "World Inequality Report", Paris, 2018.

2. Crédit Suisse Research Institute, Global Wealth Reports [Online]. Available: https://www.creditsuisse.com/corporate/en/research/researchinstitute/global-wealth-report.html [Access date: 6th, May, 2019].

3. C. DeNavas-Walt, B. D. Proctor, U.S. Census Bureau, Current Population Reports, "Income and Poverty in the United States: 2014", U.S. Government Printing Office, Washington, DC, 2015.

4. J. Bricker et al., "Changes in U.S. Family Finances from 2013 to 2016: Evidence from the Survey of Consumer Finances", Federal Reserve Bulletin, vol. 103, no. 3, Sept. 2017.

5. G. Zucman, "Global Wealth Inequality", NBER Working Paper no. 25462, Jan. 2019.

6. Institute for Policy Studies, The Billionaire Bonanza [Online]. Available: https://ips-dc.org/reportbillionaire-bonanza-2018 [Access date: 6th, May, 2019].
7. C. Stone, D. Trisi, A. Sherman, R. Taylor, "A Guide to Statistics on Historical Trends in Income Inequality" [Online]. Available: https://www.cbpp.org/research/poverty-andinequality/a-guide-to-statistics-on-historical-trendsin-income-inequality [Access date: 6th, May, 2019].

8. E. N. Wolff, "A Century of Wealth in America", Harvard University Press, Boston, 2017.

9. E. N. Wolff, "Household Wealth Trends in the United States, 1962 to 2016: Has Middle Class Wealth Recovered?" in NBER Working Paper no. 24085, Nov. 2017.

10. M. Kuhn, M. Schularick, U. I. Steins, "Income and Wealth Inequality in America, 1949-2016", Working Paper 9, Jun. 2018 [Online]. Available: at https://www.minneapolisfed.org/institute/workingpapers-institute/iwp9.pdf [Access date: 6th, May, 2019].

11. K. Fontenot, J. Semega, M. Kollar, "Income and Poverty in the United States: 2017", U.S. Census Bureau, issued Sept. 2018.

12. National Center on Family Homelessness at American Institutes for Research [Online]. Available: https://www.air.org/center/nationalcenter-family-homelessness [Access date: 6th, May, 2019].

13. L. Mishel, J. Bivens, E. Gould, H. Shierholz, "The State of Working America, 12 ${ }^{\text {th }}$ edition", 2012.

14. R. Reich, "Supercapitalism: The Transformation of Business, Democracy, and Everyday Life", Random House, New York, 2007.

15. J. Conley, "New Analysis Reveals Inequality Chasm Between CEOs and Workers 'Totally Out of Control"” [Online]. Available: https://www.commondreams.org/news/2019/05/24/n ew-analysis-reveals-inequality-chasm-betweenceos-and-workers-totally-out-control [Access date: 6th, May, 2019].

16. U.S. Census Bureau, "Current Population Survey, 1961 to 2018". Annual Social and Economic Supplements

17. Oxfam America, "Few Rewards: An Agenda To Give America's Working Poor A Raise" [Online]. Available:

https://www.oxfamamerica.org/static/media/files/Fe w Rewards Report 2016 web.pdf [Access date: 6th, May, 2019].

18. Oxfam America, "For the poverty wage in 2015 " [Online].

Available:

https://www.ocpp.org/poverty/2015-povertyguidelines [Access date: 6th, May, 2019].

19. K. J. Edin, H. L. Shaefer, "\$2.00 a Day. Living on Almost Nothing in America", Houghton Mifflin Harcourt, Boston, New York, 2015.

20. M. Desmond, "Evicted. Poverty and Profit in the American City", Crown Publishers, New York, 2016.

21. F. Stricker, "Why America Lost the War on Poverty - and How to Win it", The University of North Carolina Press, Chapel Hill, N.C., 2007. 
22. National Center on Family Homelessness at American Institutes for Research, “America's Youngest Outcasts: A Report Card on Child Homelessness", Waltham, 2014.

23. National Center on Family Homelessness at American Institutes for Research [Online]. Available: https://nlchp.org/publications/ [Access date: 6th, May, 2019].

24. E. Grande, "Guai ai poveri. La faccia triste dell'America", Ega, 2017.

25. Banca d'Italia, "La ricchezza delle famiglie italiane, 2014", Supplementi al Bollettino Statistico, no 69, Dec. 2015

26. Crédit Suisse Research Institute, "Global Wealth Databook 2018" [Online]. Available: https://www.creditsuisse.com/corporate/en/research/researchinstitute/global-wealth-report.html [Access date: 6th, May, 2019].

27. Istat, "Consumi e condizioni economiche delle famiglie", Serie storiche [Online]. Available: http://seriestoriche.istat.it/index.php?id=1\&no cach $\mathrm{e}=1 \&$ tx usercento centofe $\% 5$ Bcategoria $\% 5 \mathrm{D}=11 \&$ tx_usercento_centofe $\% 5$ Baction $\% 5 \mathrm{D}=$ show\&tx_use rcento_centofe $\% 5 \mathrm{Bcontroller} \% 5 \mathrm{D}=$ Categoria\&cHas $\mathrm{h}=310 \mathrm{a} 7 \mathrm{~b} 27 \mathrm{a} 9 \mathrm{c} 64114926 \mathrm{f} 45 \mathrm{f06a094fd4}$ [Access date: 6th, May, 2019].

28. Istat, "La povertà in Italia nel 2000" [Online]. Available:

https://www.edscuola.it/archivio/handicap/poverta.p df [Access date: 6th, May, 2019].

29. Istat, "La povertà in Italia" [Online]. Available: https://www.istat.it/it/archivio/217650 [Access date: 6th, May, 2019].

30. Istat, "Povertà relativa e assoluta" [Online]. Available:

https://www.istat.it/it/archivio/povert $\% \mathrm{C} 3 \% \mathrm{~A} 0+$ rela tiva+e+assoluta [Access date: 6th, May, 2019].

31. https://www.istat.it/it/files//2017/07/Report_Povert \%C3\%A0 2016.pdf

32. Crédit Suisse Research Institute, "Global Wealth Report 2016" [Online]. Available: https://www.creditsuisse.com/corporate/en/research/researchinstitute/global-wealth-report.html [Access date: 6th, May, 2019].

33. Istat, "Rapporto annuale della situazione del paese, Sintesi 2018" [Online]. Available: https://www.istat.it/it/archivio/214230 [Access date: 6th, May, 2019].

34. Istat, "Rapporto annuale 2018", tav. 2.2 [Online]. Available: https://www.istat.it/storage/rapportoannuale/2018/capitolo2.pdf [Access date: 6th, May, 2019].

35. Crédit Suisse Research Institute, "Global Wealth Report 2017” [Online]. Available: https://www.creditsuisse.com/corporate/en/research/researchinstitute/global-wealth-report.html [Access date: 6th, May, 2019].

36. Oxfam Italia, "La disuguaglianza in Italia" [Online]. Available: $\quad$ https://www.oxfamitalia.org/wp-
content/uploads/2019/01/Scheda-Italia InsertoRapporto-Davos_2019.pdf [Access date: 6th, May, 2019].

37. Crédit Suisse Research Institute, "Global Wealth Report 2018: US and China in the lead" [Online]. Available: $\quad$ https://www.creditsuisse.com/corporate/en/articles/news-andexpertise/global-wealth-report-2018-us-and-chinain-the-lead-201810.html [Access date: 6th, May, 2019].

38. L. Tronti, "Crescita occupazionale, lavoro discontinuo e semioccupazione. La crisi del mercato del lavoro è finita o c'è un problema di misurazione?" in Menabò di Etica ed Economia, no 79, Mar 2018 [Online]. Available: https://www.eticaeconomia.it [Access date: 6th, May, 2019].

39. C. A. Ricci, F. Bloise, "L'andamento di lungo periodo della distribuzione salariale in Italia", in Menabò di Etica ed Economia, no 90, Sept. 2018 [Online]. Available: https://www.eticaeconomia.it [Access date: 6th, May, 2019].

40. M. Ruffolo, "Lavoro, la crescita dimentica i salari. Ecco chi paga i lunghi anni della crisi", La Repubblica, 23 Oct 2017 [Online]. Available: https://www.repubblica.it/economia/affari-efinanza/2017/10/23/news/lavoro la crescita diment ica i salari ecco chi paga i lunghi anni della cri si-179077712/ [Access date: 6th, May, 2019].

41. VII Rapporto RBM-Censis [Online]. Available: https://www.quotidianosanita.it/allegati/allegato242 1529.pdf [Access date: 6th, May, 2019].

42. VIII Rapporto RBM-Censis [Online]. Available: https://www.quotidianosanita.it/allegati/allegato593 3767.pdf [Access date: 6th, May, 2019].

43. The World Inequality Lab, "World Inequality Report", Paris, 2018, Executive summary [Online]. Available: https://wir2018.wid.world/executivesummary.html [Access date: 6th, May, 2019].

44. World Bank, Poverty overview [Online]. Available: https://www.worldbank.org/en/topic/poverty/overvi ew [Access date: 6th, May, 2019].

45. J. Hickel, "The Divide: A Brief Guide to Global Inequality and its Solutions", Random House UK, 2018.

46. Crédit Suisse Research Institute, "Global Wealth Report 2018" [Online]. Available: https://www.creditsuisse.com/corporate/en/research/researchinstitute/global-wealth-report.html [Access date: 6th, May, 2019]. 